
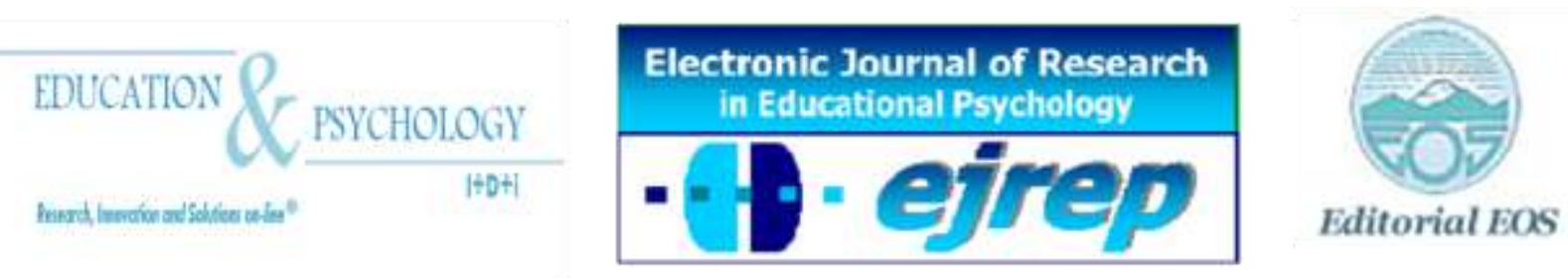

\title{
The Use of Differential Reinforcement to Decrease the Inappropriate Verbalizations of a Nine-Year-Old Girl with Autism
}

\author{
Megan J. Thompson, T. F. McLaughlin, \\ K. Mark Derby
}

Department of Special Education, Gonzaga University, Spokane, WA

USA

Correspondence: Dr. T. F. McLaughlin, Department of Special Education, Gonzaga University, Spokane, WA 99258-0025, USA E-mail: mclaughlin@gonzaga.edu; tim.mclaughlin6@comcast.net

(c) Education \& Psychology I+D+i and Editorial EOS (Spain) 


\begin{abstract}
Introduction. The purpose of this study was to decrease the number of talk-outs displayed with a $3^{\text {rd }}$ grade student with autism. She engaged in these behaviors during work time, specialty classes such as physical education, music and library, and group work.

Method. A multiple baseline probe design was used to measure the effectiveness of differential reinforcement with a token economy treatment package. A functional relationship was demonstrated between the reduction in talk-outs and the implementation of a differential reinforcement of an alternative behavior reinforcement schedule (DRA).
\end{abstract}

Results. The participant's talk-outs decreased across all settings from an average of 10.9 in baseline to a mean 3.1 talk outs during differential reinforcement within a token economy.

Conclusion. The use of the positive procedures in the classroom to reduce a problem social behavior is discussed.

Keywords: differential reinforcement, autism, classroom interventions, token economy, disruptive behaviors

Reception: 01/07/2011 Initial acceptance: 01/28/2011 Final acceptance: 03/24/2011 


\section{El uso de refuerzo diferencial para reducir las verbalizaciones inapropiadas de una alumna autista de Educación Primaria}

\section{Resumen}

Introducción. El propósito de este estudio fuea disminuir el número de charla-salidas visualizadas con un estudiante de tercer grado con autismo. Esta alumna había incorporado estos comportamientos durante tiempo de trabajo, clases de la especialidad tales y trabajo de grupo.

Método. Se utilizó un diseño de línea base múltiple para poner a prueba la relación y medir la eficacia del refuerzo diferencial, en el conjunto del tratamiento de economía simbólica.

Resultados. Se demostró una relación funcional entre la reducción en charla-salidas y la puesta en práctica de un refuerzo diferencial de un horario alternativo del refuerzo del comportamiento (DRACMA).

Resultados. Las charla-salidas de la participante disminuyeron a través de todas las configuraciones de una media de 10,9 en línea de fondo salidas malas a las 3,1 de una charla durante el refuerzo diferenciado. Las charla-salidas del participante disminuyeron a través de todas las configuraciones de una media de 10,9 en hable las salidas durante el refuerzo diferenciado dentro de una economía simbólica.

Conclusiones. Se discute la eficacia del uso de los procedimientos diferenciales de reforzamiento positivo en el salón de clases para reducir un comportamiento social problemático.

Palabras Clave: del refuerzo diferenciado con un conjunto del tratamiento de la economía simbólica.

Recepción: 07/01/2011 Aceptación inicial: 28/01/2011 Aceptación final: 24/03/2011 


\section{Introduction}

Autism is a disability characterized by lack of communication and social Functioning (Lovass, 1987). Research suggests that an intensive early behavioral intervention remains the best treatment currently available for autistic children (Fenske, Zalenski, Krantz, \& McClannahan, 1985; Lovaas, 1987; Thompson, 2007). The prevalence of children diagnosed with autism in the last 10 yours has increased at an unprecedented rate (Heward, 2008; Thompson, 2007). The Center for Disease Control and Preventions states, "CDC's Autism and Developmental Disabilities Monitoring (ADDM) Network released data in 2007 that found about 1 in 150 8-year-old children in multiple areas of the United States had ASD," (Center for Disease Control, 2008). Across the country, special education teachers are seeing the increased numbers of students in their classes, and in some schools special education programs have dedicated classrooms specifically for autism.

Students diagnosed with autism have specific characteristics associated with their level of functioning as well as their academic abilities. Each student may function at varied levels of social, functional, and achievement capabilities. A symptom in one child with autism may be mild or non-existent and in another child the symptom may be quite pronounced (Cohen \& Spenciner, 2005). Due to this variance teachers have been forced to make changes within their classroom to accommodate this group of students (Heward 2009).

Almost all students diagnosed with autism exhibit discrepancies in social behavior. Even children with language competence struggle with initiating conversation and responding to the conversation of others, appropriate turn-taking, prosody, speech detail, preservation, and attention to others during conversation (R. Koegel, L. Koegel, Frea, \& Smith, 1995; R. Koegel \& L. Koegel, 1995). Students who suffer from this discrepancies in social areas unfortunately miss many learning opportunities because of these issues in communication. Fortunately many educators have developed useful strategies to help students improve communication, thus, increasing learning opportunity in other areas (Thompson, 2007).

For many students, differential reinforcement procedures can be effective in eliciting appropriate communication and decreasing inappropriate verbalizations (Alberto \& Troutman, 2008; Champagne, Ike, McLaughlin, \& Williams, 1990; Cooper, Heron, \& He- 
ward, 2007). One strategy in particular that many educators like to implement for problem behavior has been differential reinforcement of alternative and other behaviors (Champagne et al., 1990; Dietz \& Repp, 1973, 1974). The differential reinforcement of lower or lower rates of behaviors has been advocated as a non-aversive alternative to manage classroom behaviors (Alberto \& Troutman, 2008; Copper et al., 2007; Homer, Dunlap, Koegel, Carr, Sailor, Anderson, et al., 1990; Martens, Witt, Elliott, \& Darveaux, 1985; Witt \& Robins, 1985). Dietz and Repp $(1973,1974)$ conducted a series of studies using differential reinforcement of lower rates (DRL) of responding to decrease inappropriate behavior. They employed two different types of reinforcement schedules. In their first study they implemented both a criterion-based and a response-based DRL schedule with an 11-year-old boy with moderate mental retardation. Specifically, he was rewarded with free playtime by emitting three or fewer talk out in a 50-minute period. In their second experiment with an entire class of students with moderate mental retardation, they rewarded each member of the class with two pieces of candy if the entire class had fiver or fewer talk outs within a specific time period. In their final experiment, an entire general education high school class of 15 girls was rewarded for reducing their number of inappropriate social discussions. After their baseline performance had stabilized, Deitz and Repp (1973) gradually lowered the criterion (six or fewer, three or fewer, two or fewer, and zero) for the class to earn a free period on Friday. Deitz and Repp (1974) were able to replicate the effects of using differential reinforcement to reduce classroom misbehavior. The major advantage of using a DRL procedure is that one can reduce unwanted behavior(s) through the use of reinforcement. Also, many educators view these procedures has highly acceptable for use in the classroom (Deitz \& Repp, 1984; Deitz, Slack, Schwarzmueller, Wilander, Weatherby, \& Hilliard, 1978; Elliott, Witt, Galvin, \& Peterson, 1984; Martens, Witt, Elliott, \& Darveaux, 1985; Witt \& Martens, 1983, 1984). A possible problem with using these procedures is the dilemma of what to do when the child or class fails to meet the criterion early in the session. After losing the ability to acquire reinforcement, one student or class may emit a large number of these behaviors. In addition, based on strict adherence to treatment fidelity, there maybe little or nothing that a teacher can do. One recommendation has been to break a whole session into a series of shorter times (Dietz \& Repp, 1984; Dietz, Slack, Schwarzmueller, Wilander, Weatherby, \& Hilliard, 1978) or to implement an aversive procedure where the excess behavior from the previous day counts toward the next day's score. 
Positive procedures such as differential reinforcement have been suggested as a more socially acceptable intervention for use by school personnel (Martens et al., 1985; Witt \& Robins 1985). Differential reinforcement procedures are often employed as part of an ongoing token economy (McLaughlin \& Williams, 1988). In the present investigation, we simply added a differential reinforcement procedure to the on-going token reinforcement ticket system found in the classroom. The purpose of this study was to decrease the number of talkouts with a $3^{\text {rd }}$ grade student with autism. She engaged in a wide range of inappropriate behaviors at school. One behavior that her classroom teacher wished to change was her frequency of inappropriate verbalizations. Typically, she emitted these behaviors during calendar, work time, specialty classes such as physical education, music or library, and group work time. It was felt that a reduction in these behaviors would make her more likely to be accepted by her classmates and her general education peers.

\section{Method}

\section{Participant and Settings}

"Molly" was a 9-year-old third grade student diagnosed with autism. She was placed in a self-contained special education classroom located in a large urban school district in the Pacific Northwest. Throughout the investigation, the medication to help manage her behavior was available to the researchers. Her reading and math achievement was at the first grade level, and written language was at kindergarten level according to her current achievement test scores taken from the Woodcock-Johnson III Test of Achievement (Woodcock, McGrew, \& Mather, 2001).

Data were gathered within three settings. The first setting was during calendar time in "Molly's" classroom. The second setting was at group time in "Molly's" classroom. The third setting was during specialty classes that consist of physical education, which tool place in the gym, music which took place in the music room, and library which took place in the school's library. People present during data collection included the classroom teacher, two instructional assistants, the class nurse, six other classmates, and the first author. Sessions lasted about 20 minutes, with one to four sessions each day.

\section{Dependent Variable and Measurement Procedures}

The dependent variable was the number of talk-outs "Molly:" emitted during a 20- 
minute session. A talk-out was defined as any comment made by the student without being called upon by her teacher(s), or a vocalization unrelated to a medical emergency within the classroom. If the student paused in between talk-outs for less than $5 \mathrm{~s}$ between comments, it was recorded as one talk-out. However, when she changed to a new subject, it was recorded as an additional talk-out. Examples included asking for a turn during an activity when it was not allowed, commenting on the activity in general, or telling other students what to do during the activity.

\section{Experimental Design and Conditions}

The design of the study was a multiple baseline probe design (Barlow, Nock, \& Hersen, 2008) across three settings. The first setting was calendar time, the second setting was group work time, and the third setting was during specialty classes (i. e., physical education, music and library).

Baseline. Baseline data were taken in each setting. For calendar baseline was taken for three sessions. For group work time baseline data were taken for five sessions. For specialty classes (physical education, library, or music) baseline was recorded for 11 sessions. Typical classroom procedures were in place during baseline. If the student talked-out she was (a) reminded to raise her hand and wait to be called upon by the teacher or aide, (b) simply ignored; and (c) asked to be quiet. The lead teachers in each setting were informed by the researcher that data were being taken and to interact normally with "Molly."

$D R$ and token economy (DR + token economy). The intervention was initially implemented during calendar time. Before starting intervention in each setting, we explained the contingencies for earning tickets to "Molly." She was informed that we were going to work on listening and raising her hand. "Molly" was also informed she could trade in her tickets for prizes after she had earned five tickets. Before each session, the first author reminded "Molly" she could earn a ticket for not talking-out. She was also the praised at various times for not talking-out and for raising her hand. Phrases such as "good work, " "nice raising your hand, " or "excellent waiting" were employed. All of the other adults present in the classroom were told to maintain their behavior with "Molly." This included correcting her if she talked out and/or asking her to be quiet.

At the end of each session, "Molly" and the first author sat together and discussed her performance. "Molly" would first estimate the number of talk-outs she had then the researcher 
would show her the tally sheet. If she had improved by at least one talk-out over that recorded in the previous session, she earned a ticket. For example, if she had four talk outs the previous day, she could earn a ticket for three or fewer talk outs. In addition, "Molly" was rewarded with an extra ticket per session if she had one or no talk-outs. If she did not earn a ticket, she was required to tell the first author ways she could improve in the next session so she could earn a ticket. Once "Molly" had accumulated five tickets, she was awarded a toy chosen from a classroom treasure chest.

\section{Data Collection and Interobserver Agreement}

An event recording system was used to collect data. For each talk out, a tick mark was made on the data collection sheet, with one sheet used each day. Twenty-minute sessions were conducted across one to three settings each day. Interobserver agreement was gathered for $30 \%$ of the sessions. Simultaneous but independent data recording by two observers. These observers consisted of the classroom nurse, the lead teacher, an aide or a substitute. More than $70 \%$ of the sessions, reliability of measurement was taken by the classroom nurse. This second observer sat as far away as possible from the first author but was able to observe the student. Each observer used his/her own data sheet. Interobserver is calculated by dividing the smaller number of talk out by the larger number and multiplying by 100 . The mean agreement was $88 \%$ (range 70 to $100 \%$ ).

\section{Results}

\section{Baseline}

During baseline in calendar, "Molly" had a mean score of 12.3 talk-outs per session. The range of scores for calendar was 8 to 19 talk-outs. During baseline in group work time, she emitted an average of 18 talk-outs, with a range of 4 to 41 . During baseline in her specialty classes (PE, library, music) "Molly" had a mean of 9 talk-outs with a range of 4 to 23 .

\section{DRA and with token economy}

During intervention in calendar, "Molly's" mean number of talk-outs decreased to a mean of 4.0, with a range of 0 to 12 . For group time, Molly's mean score was also declined $(M=2.8$ talk-outs with a range of 1 to 5 . During specialty classes, "Molly's" mean number of talk outs was reduced ( $M=2.1$ talk-outs; range 0 to 5$)$. Overall, a correlation was demonstrated between the number of talk-outs "Molly" emitted and the implementation of differen- 
tial reinforcement and a token economy. Overall her talk-outs did decrease across all settings from 10.9 in baseline to 3.1 in DR + token economy phase. See Figure 1.

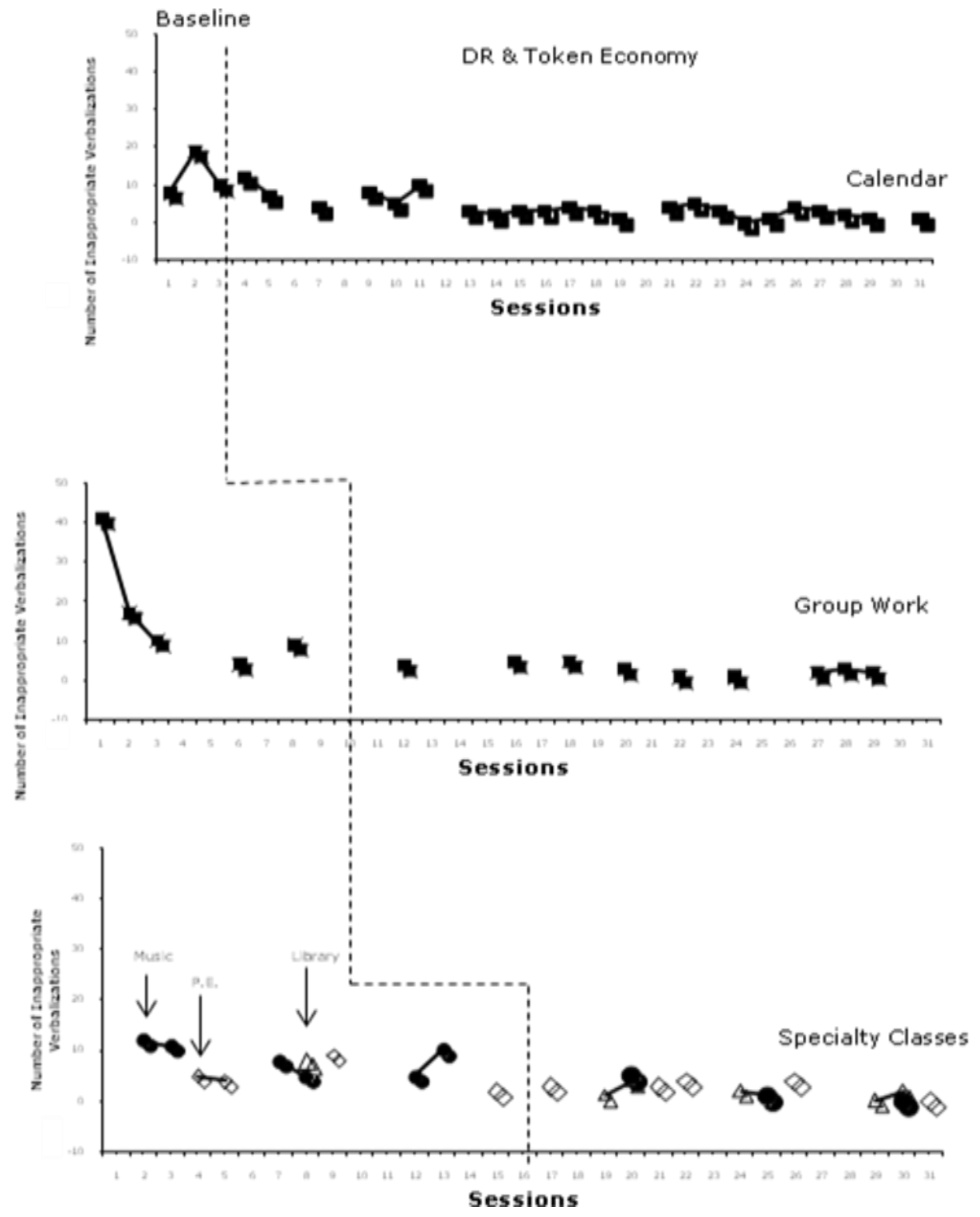

Figure 1. The number of talk-outs per setting during baseline and differential reinforcement (DR) and a token economy. 


\section{Discussion and Conclusion}

There were several strengths in this study. First, all materials were easily accessible and inexpensive for the first author. Second, the intervention of differential reinforcement and a token economy were not time consuming or difficult for the first author or classroom teacher to implement. Third, the study did not take away from "Molly's" learning opportunities nor did it adversely affect other students in the classroom. The final strength of this study was that it could be easily implemented in more settings by the classroom teacher or an instructional assistant.

The present outcomes replicate the previous work of Deitz and Repp (1973, 1974, 1984) and Deitz and colleagues (1978) in classroom settings using differential reinforcement procedures to reduce behavior. In the present analysis a student with autism was employed rather than general education students with rather low rates of misbehavior or students with mental retardation. In addition, the intervention was implemented by a student teacher from a local university with assistance from the classroom teacher. The present procedures allowed the student to gradually reduce her inappropriate verbalizations. There was a changing response criterion depending upon her previous day's totals. The reinforcement schedule was rather lean; that is, the student was able to delay earning a trinket because she had to earn five tickets before they could be redeemed. The use of positive procedures that reduce behavior have been shown to be more likely to be implemented by classroom personnel (Alberto \& Troutman, 2008; Elliott et al., 1984). Finally, the present case report provides additional evidence as to the efficacy of teacher candidates developing and making data-based decions regarding classroom practice (Carlson, McLauglin, Derby, \& Blecher, 2009; Glover, McLauglin, Derby, \& Coger, 2010).

There were limitations in the study. First, it was only conducted with one participant and this did not permit a comparison of differential reinforcement and a token economy with another student in the same class with inappropriate verbalizations. Another weakness was that data could not be taken in every setting each day. Group work time has twice as many data points as calendar or specialty classes. A final weakness was that "Molly" failed to decrease her talk-outs in each setting to zero levels. However, the first author took data on the entire class across all setting for six sessions. We found that each student emitted 1.9 talkouts per session in each setting. It appears that "Molly's" rates were very close to the ob- 
served classroom norm, and it may be unrealistic to expect "Molly" have no talk-outs across settings. Finally, since the intervention procedure had multiple components, the exact variables responsible for change "Molly's" behavior are unclear.

"Molly's" classroom teacher informed us that she will continue to differentially reinforce "Molly" and maintain the token economy system. Additional research may well include other students and/or additional target behaviors. Finally, various criteria for earning tickets, the feedback provided each day (Martens, Hiralall, \& Bradley, 1997) or type or number of tokens could be manipulated. In the present analysis the criteria was always changing based on her previous inappropriate behaviors. It may well be that other types of rewards as well as monitoring systems could be successfully implemented. 


\section{References}

Alberto, P. A., \& Troutman, A.C. (2008). Applied behavior analysis for teachers. ( $8^{\text {th }}$ ed.) Upper Saddle River, NJ: Merrill/Prentice Hall.

Barlow, D. H., Nock, M., Hersen, M. (2008). Single case research designs: Strategies for studying behavior change ( $3^{\text {rd }}$ ed.). New York: Allyn and Bacon.

Carlson, B., McLaughlin, T. F., Derby, K. M., \& Blecher, J. (2009). Teaching children with autism and developmental delays to write. Electronic Journal of Research in Educational Psychology, 17 (1), 225-238.

Center for Disease Control and Prevention. What is the prevalence of Autism?. Retrieved May 6, 2008, http://www.cdc.gov/ncbddd/autism/faq_prevalence.htm

Champagne, J. M., Ike, E. C., McLaughlin, T. F., \& Williams, R. L. (1990). Use of differential reinforcement of lower rates of behavior and self-monitoring with a delinquent adolescent in residential setting. Journal of Instructional Psychology, 16, 123-132.

Cohen, L., \& Spenciner, L. J. (2005). Teaching students with mild and moderate disabilities: Research-based practices. Upper Saddle NJ: Pearson/Prentice Hall.

Cooper, J. O., Heron, T. A., \& Heward, W. L. (2007). Applied behavior analysis ( ${ }^{\text {nd }}$ ed.). Upper Saddle River, NJ: Pearson Education.

Deitz, S. M., \& Repp, A. C. (1973). Decreasing classroom misbehavior through the use of DRL schedules reinforcement. Journal of Applied Behavior Analysis, 6, 457-463.

Deitz, S. M., \& Repp, A. C. (1974). Differentially reinforcing low rates of misbehavior with normal elementary school children. Journal of Applied Behavior Analysis, 7, 622.

Deitz, S. M., \& Repp, A. C. (1984). Reducing behavior through reinforcement. Exceptional Education Quarterly, 3, 34-46.

Deitz, S. M., Slack, D. J., Schwarzmueller, E. B., Wilander, A. P., Weatherby, T. J., \& Hilliard, G. (1978). Reducing inappropriate behavior in a special classroom by reinforcing average interrresponse times: Interval DRL. Behavior Therapy, 9, 37-46.

Elliott, S. N., Witt, J. C., Galvin, G. A., \& Peterson, R. (1984). Acceptability of positive and reductive behavioral interventions: Factors that influence teachers' decisions. Journal of School Psychology, 22, 353-360.

Fenske, E. C., Zalenski, S., Krantz, P. J., \& McClannahan, L. E. (1985). Age at intervention and treatment outcomes for autistic children in a comprehensive intervention program. Analysis and Intervention in Developmental Disabilities, 5, 49-58. 
Glover, P., McLaughlin, T. F., Derby, K. M., \& Gower, J. (2010). Using a direct instruction flashcard system employing a back three contingency for errors with two students with learning disabilities. Electronic Journal of Research in Educational Psychology, 8 (2), 457-482.

Heward, W. L. (2009). Exceptional children: An introduction to special education $\left(9^{\text {th }}\right.$ ed). . Upper Saddle River, NJ: Merrill/Prentice Hall.

Horner, R. H., Dunlap, G., Koegel, R. L., Carr, E. G., Sailor, W., Anderson, J. et al. (1990). Toward a technology of "nonaversive" behavioral support. The Journal of The Association for the Severely Handicapped, 15(3), 3-10.

Koegel, R. L., \& Koegel, L. K. (Eds.). (1995). Teaching children with autism: Strategies for initiating positive interactions and improving learning opportunities. Baltimore: Paul $\mathrm{H}$ Brooks Publishing.

Koegel, R. L., Koegel, L. K., Frea, W. D., Smith, A. E. (1995). Emerging interventions for children with autism. In R. L., Koegel, \& L. K. Koegel (Eds.). Teaching children with autism: Strategies for initiating positive interactions and improving learning opportunities (pp. 1-15). Baltimore: Paul H Brookes Publishing,

Lovaas, O. I. (1987). Behavioral treatment and normal educational and psychological functioning in young autistic children. Journal of Counseling and Clinical Psychology, 55, $3-9$.

Martens, B. K., Hiralall, A. S., \& Bradley, T. A. (1997). A note to teacher: Improving student behavior through goal setting and feedback. School Psychology Quarterly, 12, 33-41.

Martens, B. K., Witt, J. C., Elliott, S. N., \& Darveaux, D. X. (1985). Teacher judgments concerning the acceptability of school-based interventions. Professional Psychology Research and Practice, 16, 191-198.

McLaughlin, T. F., \& Williams, R. L. (1988). The token economy in the classroom. J. C. Witt, S. N. Elliott, \& F. M. Gresham (Eds). Handbook of behavior therapy in education (pp 469-487). New York: Plenum.

Thompson, T. (2007). Making sense of autism. Baltimore: Paul H. Brookes Publishing.

Witt, J. C., \& Martens, B. K. (1983). Assessing the acceptability of behavioral interventions used in classrooms. Psychology in the Schools, 20, 510-517.

Witt, J. C., \& Martens, B. K. (1984). Acceptability of behavioral interventions used in classrooms: the influence of amount of teacher time, severity of behavior problem. Behavior Disorders, 2, 95-104. 
Witt, J. C., \& Robbins, J. R. (1985). Acceptability of reductive interventions for the control of inappropriate child behavior Journal of Abnormal Child Psychology, 13, 59-67.

Woodcock, R. W., McGrew, K. S., \& Mather, N. (2001). Woodcock Johnson Psychoeducational Battery. Reading Meadows, IL: Riverside Publishing. 